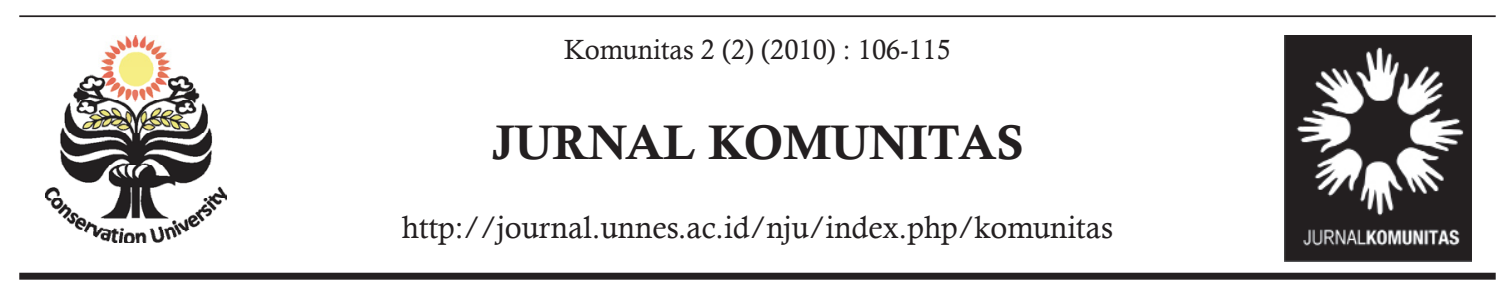

\title{
PERGULATAN HIDUP PEREMPUAN PEMECAH BATU
}

\section{Sri Suhartini $\bowtie$}

MA al-Hikmah Magelang, Jawa Tengah, Indonesia

\section{Info Artikel}

Sejarah Artikel:

Diterima Juni 2010

Disetujui Juli 2010

Dipublikasikan September 2010

Keywords:

Double burden;

Women;

Breaking stones.

\begin{abstract}
Abstrak
Semakin terbatasnya lahan pertanian dan berkembangnya teknologi pertanian, mengakibatkan penurunan kesempatan kerja perempuan disektor pertanian di daerah pedesaan. Oleh karena itu muncul berbagai alternatif pekerjaan yang ditekuni perempuan di pedesaan. Bidang pekerjaan yang dipilih perempuan desa umumnya sebagai buruh, salah satunya adalah buruh pemecah batu. Penelitian ini bertujuan untuk mengetahui kehidupan sosial dan ekonomi perempuan pemecah batu, mengetahui pembagian waktu perempuan sebagai ibu rumah tangga dan sebagai pemecah batu dan mengetahui relasi antara pekerjaan menjadi pemecah batu dengan pola pengambilan keputusan dalam rumah tangga para perempuan pemecah batu. Metode yang digunakan adalah pendekatan deskriptif kualitatif dan dilakukan pada para perempuan pemecah batu di Desa Kebondalem Kecamatan Gringsing Kabupaten Batang. Pengumpulan data menggunakan teknik wawancara mendalam dan observasi partisipasi terbatas. Hasil penelitian menunjukkan bahwa para perempuan mendapat keuntungan dengan bekerja sebagai pemecah batu dan dengan pekerjaan ini mereka dapat memperluas hubungan sosial dengan masyarakat luas. Akan tetapi kehidupan ekonomi para perempuan pemecah batu tidak mengalami perubahan karena pendapatan yang diperoleh belum mampu untuk memenuhi kebutuhan hidupnya. Alokasi waktu yang dicurahkan perempuan pemecah batu lebih banyak jika dibandingkan oleh para pekerja laki - laki dalam sehari-hari. Dengan demikian perempuan pemecah batu memiliki beban yang lebih berat jika dibandingkan dengan suami.
\end{abstract}

\begin{abstract}
The more limited agricultural land and the development of agricultural technology results in the decrease of female employment in the agricultural sector in rural areas. This condition is characterized by the emergence of alternative jobs for rural women. Such an alternative is stone-breaking labor. The objective of this study is to examine the social and economic life of breaking stones women, the distribution of time of woman as housewives and stone-breakers, and the relation between the work as stone-breaker and the pattern of decision-making in the household of stone-breaker women. The reasearch method used is descriptive qualitative approach and the research is conducted in the village of Batang Gringsing Kebondalem District. Data collection technique were in-depth interviews and limited participant observation. Research results show that women have been benefited by working as a stone-breaker from which they can expand social relations with wider community. However, the low income job does not change their life because the income has not been able to meet their needs. Reseach also finds that the allocation of time devoted by stone-breaker women is far beyond men's time. Thus, stone-breaker women have a heavier burden compared to their husbands.
\end{abstract}

(C) 2010 Universitas Negeri Semarang

\footnotetext{
Alamat korespondensi:

MA Al-Hikmah Magelang, 57749

E-mail: suhartini@gmail.com
}

ISSN 2086-5465 


\section{PENDAHULUAN}

Menyempitnya lahan pertanian dan semakin berkembangnya teknologi pertanian padi di sawah, mengakibatkan penurunan kesempatan kerja perempuan disektor pertanian di daerah pedesaan. Perempuan kehilangan kesempatan berburuh tani pada waktu menanam, menyiang dan panen. Oleh karena itu mereka memerlukan alternatif untuk memperoleh pekerjaan diluar pertanian. Bidang pekerjaan yang dipilih perempuan desa umumnya sebagai pekerja atau buruh (Abdullah 2003: 222; Christina, 2010).

Bekerja dengan imbalan kecil merupakan kenyataan hidup yang harus di alami perempuan terutama perempuan yang tinggal di daerah pedesaan. Kondisi ekonomi yang kurang menguntungkan bagi perempuan yang tinggal di daerah pedesaan menyebabkan perempuan harus bisa melakukan pekerjaan rumahtangga diusia yang relatif muda (Abdullah 2003: 220). Lebih lanjut Abdullah menjelaskan bahwa keterlibatan perempuan dalam kegiatan ekonomi keluarga di pengaruhi oleh beberapa faktor pertama, tekanan ekonomi kedua, tidak ada peluang kerja lain yang sesuai dengan keterampilannya ketiga, lingkungan keluarga yang sangat mendukung dalam bekerja (Abdullah, 2003: 226). Selain itu berdasarkan penelitian Silvia (2009), faktor pendidikan juga sangat berpengaruh terhadap partisipasi kerja perempuan di sektor publik. Semakin tinggi pendidikan perempuan maka akan lebih besar pula kesempatan untuk mendapatkan pekerjaan.

Menurut konsep WID (women in development) penyebab keterbelakangan perempuan karena perempuan tidak berpartisipasi dalam pembangunan. Perempuan mengalami pengekangan dalam bidang ekonomi, teknologi, pengetahuan dan kekuasaan (Fakih 2006: 60). Dalam strategi WID perempuan diharapkan dapat sejajar dengan laki-laki akan tetapi strategi tersebut gagal karena perempuan masih saja diposisi subordinat yaitu di bawah laki-laki. Padahal sebagaimana dikemukakan oleh Supartiningsih, seharusnya posisi laki - laki dan perempuan adalah setara karena mereka bukan lawan jenis, melainkan pasangan jenis (Supartiningsih, 2003:54)

Ketidak setaraan laki - laki dan perempuan dalam dunia sosial juga sangat merugikan kaum perempuan ketika mereka terjun ke dunia bekerja. Hal tersebut ditemukan oleh Daulay dalam penelitiannya tentang buruh jamu gendong di Kota Medan. Oleh sebab itu diperlukan kepedulian lembaga yang peduli dengan keadilan jender untuk selalu aktif mendampingi para buruh perempuan yang termarjinalkan (Daulay, 2006).

Berdasarkan tuntutan ekonomi, seorang perempuan selain sebagai ibu rumah tangga juga bekerja membantu penghasilan suami. Hal inilah yang terjadi di Desa Kebondalem Kecamatan Gringsing Kabupaten Batang bahwa pada umumnya perempuan di Desa Kebondalem selain sebagai ibu rumah tangga juga memiliki pekerjaan sebagai pemecah batu. Pekerjaan memecah batu banyak dilakukan oleh warga Desa Kebondalem di sepanjang tepian Sungai Kuto yang melintasi desa Kebondalem.

Pekerjaan pemecah batu ini dibedakan antara perempuan dan laki-laki. Biasanya perempuan bekerja memecahkan batu krikil (batu kecil) sedangkan bagi laki-laki bekerja memecahkan batu belah (batu besar). Namun pada saat sekarang ini, pekerjaan pemecah batu hanya dikerjakan oleh kaum perempuan, sedangkan kaum laki-laki ada yang menekuni pekerjaan ini tetapi hanya sebagai sampingan dan laki-laki lebih memilih pekerjaan lain seperti sebagai pengayuh becak, penggali pasir, dan kuli panggul.

Perempuan di Desa Kebondalem selain bekerja memecah batu, juga harus mengurus anak-anak dan suami. Peran ganda perempuan pemecah batu telah mempengaruhi alokasi wewenang atau kekuasaan dalam keluarga. Seorang istri yang bekerja akan memiliki wewenang atau kekuasaan yang berbeda dalam keluarga apabila dibandingkan dengan seorang istri yang tidak bekerja, terutama dalam pola pengambilan keputusan. Selain itu dengan seorang istri bekerja sebagai pemecah batu 
maka status dan peranan dalam keluarga dan masyarakat juga akan mengalami perubahan.

Berdasarkan latar belakang permasalahan tersebut, maka penelitian ini akan menjawab rumusan masalah berikut: Bagaimana kehidupan sosial dan ekonomi perempuan pemecah batu di Desa Kebondalem Kecamatan Gringsing Kabupaten Batang? Bagaimana pembagian waktu perempuan sebagai ibu rumah tangga dan sebagai pemecah batu? Adakah relasi antara pekerjaan menjadi pemecah batu dengan pola pengambilan keputusan dalam rumah tangga para perempuan pemecah batu di Desa Kebondalem Kecamatan Gringsing Kabupaten Batang?

\section{METODE PENELITIAN}

Penelitian ini dilaksanakan dengan pendekatan deskriptif kualitatif karena peneliti ingin mendiskripsikan secara jelas dan terperinci serta memperoleh data yang mendalam dari fokus penelitian yaitu bagaimana kehidupan sosial dan ekonomi perempuan sebagai pemecah batu, pola pengambilan keputusan perempuan pemecah batu dalam rumah tangga dan bagaimana pembagian waktu perempuan sebagai ibu rumahtangga dan sebagai pemecah batu. Penelitian dilakukan pada keluarga perempuan pemecah batu di Desa Kebondalem Kecamatan Gringsing Kabupaten Batang. Subyek dalam penelitian ini adalah tujuh orang perempuan yang bekerja sebagai pemecah batu. Dengan kriteria telah bekerja lebih dari sepuluh tahun, perempuan yang telah menikah atau berumah tangga serta yang telah memiliki anak, batasan usia antara 25-50 tahun.

Informan utama dalam penelitian ini adalah suami, anak dan keluarga dari perempuan yang bekerja sebagai pemecah batu. Sedangkan informan pendukung dalam penelitian ini adalah kepala desa, perangkat desa, juragan batu dan masyarakat Desa Kebondalem.

Pengumpulan data dalam penelitian ini menggunakan metode wawancara mendalam. Melalui wawancara, peneliti ingin mengetahui secara mendalam tentang kehidupan sosial dan ekonomi perempuan pemecah batu, pengambilan keputusan perempuan pemecah batu dalam rumah tangga dan pembagian waktu perempuan sebagai ibu rumah tangga dan sebagai pemecah batu.

Selain itu juga digunakan teknik observasi non partisipasi dengan cara melakukan pengamatan langsung terhadap subyek penelitian yaitu para perempuan pemecah batu di Desa Kebondalem Kecamatan Gringsing Kabupaten Batang. Pengamatan langsung maksudnya, mengamati dan memperhatikan kegiatan para perempuan pemecah batu, pada saat melakukan pekerjaan memecah batu maupun pada saat melakukan peranannya sebagai ibu rumahtangga.

\section{HASIL DAN PEMBAHASAN}

Desa Kebondalem terletak di Kecamatan Gringsing Kabupaten Batang Propinsi Jawa Tengah. Desa Kebondalem memiliki luas wilayah $289.680 \mathrm{Ha}$ dan berada di dataran rendah. Jarak Desa Kebondalem dari pusat Pemerintahan Kota Gringsing adalah5 KmdanjarakdariPemerintahanKota batang adalah $35 \mathrm{Km}$. Secara administratif Desa Kebondalem terbagi menjadi 5 Dukuh yaitu Dukuh Kutorejo, Dukuh Kebonsari, Dukuh Kebondalem, Dukuh Rowogebang dan Dukuh Gebanganom. Sedangkan jumlah penduduk di Desa Kebondalem secara keseluruhan adalah sebanyak 4.394 Jiwa, dengan perincian penduduk lakilaki sebanyak 2.106 Jiwa dan penduduk perempuan berjumlah 2.288 Jiwa.

Dilihat dari aspek pendidikan, mayoritas penduduk Kebondalem memiliki akses yang rendah terhadap pendidikan formal. Mayoritas penduduk hanya menamatkan pendidikannya di Sekolah Dasar, hanya sebagian kecil yang mengenyam pendidikan menengah dan tinggi. Hal tersebut dikarenakan minimnya keberadaan sekolah terutama tingkat menengah di Desa Kebondalem. Oleh sebab itu rata - rata masyarakat Kebondalem setelah lulus SMP memilih untuk bekerja. 
Kurangnya lapangan pekerjaan menyebabkan masyarakat Desa Kebondalem terutama yang ibu-ibu memilih pekerjaan yang dekat dengan tempat tinggal agar bisa bekerja sambil mengurus rumah tangga. Bagi yang masih berusia produktif banyak yang memilih bekerja keluar Desa Kebondalem untuk meningkatkan kesejahteraan. Seperti dijelaskan oleh Ibu Sulati:

Bade kerjo nopo meleh mbak, wong teng mriki niku boten wonten kerjaan liyane. Katahe gih do kerjo mecahi watu niki seng di lakoni ibu-ibu teng mriki tros kerjo mecah watu niki geh boten angel mbak.

(mau kerja apa lagi mbak, disini tidak ada pekerjaan lain. Kebanyakan dari ibu-ibu di sini bekerja memecah batu selain itu pekerjaan ini juga tidak sulit)

Suami perempuan pemecah batu tidak merasa keberatan jika istri bekerja, karena dengan istri bekerja akan menambah penghasilan keluarga dan dapat memenuhi kebutuhan keluarga selain itu, yang terpenting bagi seorang istri yang memiliki beban ganda, tidak melupakan pekerjaannya sebagai ibu rumah tangga yang harus mengurus suami dan anak. Hal tersebut diungkapkan oleh Pak Rohani sebagai berikut:

Kulo mboten kabotan menawi estri kulo nyambut damel dados tukang mecah watu, engkang paling penting mboten nglalekke kewajiban dhateng kluwargo. Kejawi meniko kanthi estri kulo nyambot damel saget ngewangi kulo kangge nyukupi kebutuhan kluwargo.

(Saya tidak keberatan istri saya bekerja sebagai pemecah batu, yang penting tidak menelantarkan keluarga. Selain itu juga dengan istri saya bekerja, dapat membantu kebutuhan keluarga)

Dalam kehidupan sosial kemasyarakatan, hubungan dengan sesama perempuan pemecah batu terjalin dengan baik. Hal ini dibuktikan dengan pada saat memecahkan batu biasanya mereka sambil mengobrol karena memang jaraknya yang berdekatan. Biasanya yang dibicarakan mengenai keluarga, pendidikan anak, kebutuhan rumah tangga dan lain-lain. Selain itu tidak ada persaingan dalam bekerja karena mereka sadar bahwa sama-sama mencari uang dan masih satu desa mengapa harus bersaing. Jika ada yang bersaing umumnya orang yang bersaing tersebut akan dikucilkan. Para perempuan pemecah batu disela kesibukannya ternyata juga aktif dalam kegiatan-kegiatan yang ada di Desa Kebondalem. Kegiatan kemasyarakatan yang biasanya di ikuti adalah arisan PKK dan pengajian. Selain itu mereka juga aktif dalam kegiatan seperti selametan, puputan, mitoni dan lain-lain. Biasanya ibu-ibu membantu menyumbang tenaga dan uang. Karena dengan begitu nantinya mereka juga akan di bantu bila mengadakan acaraacara tersebut, disamping itu acara tersebut juga semakin mempererat hubungan dengan masyarakat sekitar.

Walaupun pekerjaan sebagai pemecah batu menduduki pekerjaan terendah di Desa Kebondalem akan tetapi perempuan pemecah batu tetap dihargai. Bahkan ada juga seorang ibu pemecah batu yang menjadi ketua pengajian di Desa Kebondalem, yang pengajian tersebut diikuti oleh sebagian besar masyarakat Desa Kebondalem. Hal tersebut terjadi pada diri $\mathrm{Bu}$ Suripah sebagaimana penjelasannya berikut :

Arepo gawean kulo dados tukang mecah watu, kulo boten nopo-nopo lan boten isin. Amargi niku gawean ingkang halal, malahan kulo dipercoyo dados ketua pengajian wonten Deso mriki. Sedoyo wau dipercoyo dhateng kulo amargi kulo hafal Al Quran.

(walaupun pekerjaan saya sebagai pemecah batu saya tidak apa-apa dan saya tidak malu, karena itu merupakan pekerjaan halal. Bahkan saya di percaya masyarakat Desa Kebondalem untuk menjadi ketua pengajian karena saya hafal Al Quran)

Faktor utama yang mendorong 
perempuan di Desa Kebondalem bekerja sebagai pemecah batu adalah karena pemenuhan kebutuhan hidup dan kemiskinan. Sebagian besar perempuan pemecah batu masih hidup miskin. Artinya dalam upaya pemenuhan kebutuhan primer, seperti kebutuhan makan, pakaian, rumah yang sehat dan ideal, pendidikan dan kesehatan masih dirasa berat belum lagi ditambah dengan tuntutan keluarga akan pemenuhan kebutuhan sekunder seperti membeli sepeda motor dan membeli peralatan rumah tangga. Ibu-ibu di Desa Kebondalem masih menekuni pekerjaan ini dikarenakan tidak ada pekerjaan lain yang tersedia. Selain itu dengan bekerja sebagai pemecah batu ibu-ibu bisa bekerja dan tidak meninggalkan pekerjaannya sebagai ibu rumah tangga. Tidak adanya peraturan kerja yang mengikat serta bisa berangkat dan libur kerja kapan saja menjadikan mereka tetap memilih pekerjaan ini.

Tempat tinggal yang dekat dengan sungai Kuto menjadikan ibu-ibu memilih pekerjaan ini, karena batu tersebut di ambil langsung dari sungai Kuto tersebut. Jarak antara rumah dan sungai dekat, maka para buruh perempuan hanya membutuhkan waktu 5-10 menit untuk sampai ke tempat kerja. Untuk sampai ke tempat kerja banyak dari para buruh perempuan pemecah batu ini yang berjalan kaki dan naik sepeda. Biasanya laki-laki yang mencari batu di sungai sedangkan ibu-ibu yang memecahkan batunya.
Selain dekat dengan sungai Kuto, hanya sedikit perempuan di Desa Kebondalem yang memiliki alasan lain untuk bekerja sebagai pemecah batu yaitu untuk mengisi waktu dan sebagai pekerjaan sampingan. Para perempuan yang memilih bekerja memecah batu sebagai pekerjaan sampingan biasanya berasal dari keluarga yang mampu sehingga pendapatan yang pas-pasan sebagai pemecah batu tidak menjadi masalah. Hal tersebut seperti yang terjadi pada diri $\mathrm{Bu}$ Kasripah sebagaimana dituturkan pada peneliti sebagai berikut :

Gawean mecah watu niki mung dados sampingan mawon, amargi timbang kulo nganggur teng griyo ingkang becik kulo pados gawean, tapi menawi putu kulo teng griyo kulo milih ngurus putu.

(pekerjaan pemecah batu ini Cuma sebagai sampingan saja. Karena dari pada saya menganggur di rumah lebih baik cari kesibukan, biasanya kalau ada cucu saya di rumah, saya lebih memilih mengurus cucu).

Berbeda dengan ibu Kasripah, sebagian besar perempuan pemecah batu lainnya memandang pekerjaan yang digeluti, tidak hanya sekedar pekerjaan sampingan saja. Para perempuan pemecah batu ini mulai merasa tergantung dan akhirnya benarbenar menjadi pekerjaan utama. Terutama setelah menjadi pencari nafkah utama dalam

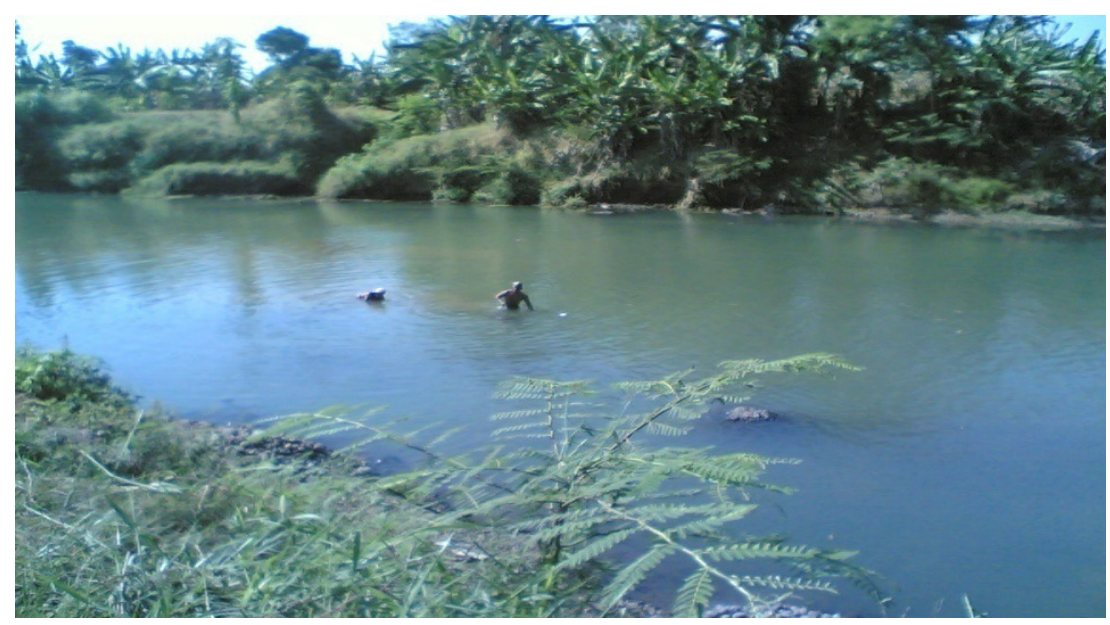

Gambar 1. Sungai Kuto Sebagai Sumber Kehidupan Masyarakat Kebondalem 
keluarga.

Dalam sistem pemberian gaji, perempuan pemecah batu terlebih dahulu meminjam uang kepada juragan atau bos (hutang atau ngebon) biasanya uang yang dipinjam sekitar Rp. 600.000,00 - Rp. $1000.000,00$. tidak ada jangka waktu dalam mengembalikan uang tersebut, yang penting semakin giat bekerja dan semakin banyak batu yang dipecahkan maka semakin cepat dalam mengembalikan uang tersebut. Dalam mengembalikan uang yang dipinjam tersebut tidak dalam bentuk uang akan tetapi dalam bentuk batu yang telah di pecahkan.

Dari upah bekerja yang terkumpul, apabila seorang perempuan pemecah batu mampu memecahkan batu sebanyak $1 \quad 1 / 2$ kubik dalam satu minggu dan tiap 1 kubik ada 48 serok. Jadi jika dalam satu minggu bisa menghasilkan sampai $1 \frac{1 / 2}{2}$ kubik berarti ada 72 serok batu yang telah dipecahkan. Tiap 1 kubiknya dihargai Rp. 30.000,00 maka dalam satu bulan menghasilkan uang sebesar Rp. 180.000,00 uang sebesar ini tidak cukup untuk memenuhi kebutuhan primer dan sekunder seperti makan, minum, memperbaiki rumah dan sebagainya. Keluarga perempuan pemecah batu bisa dikatakan memiliki kondisi ekonomi yang miskin, ukuran yang digunakan adalah pengeluaran keluarga lebih kecil daripada $320 \mathrm{Kg}$ nilai tukar beras per orang per tahun. Meskipun begitu masih banyak perempuan di Desa Kebondalem yang memilih bekerja sebagai pemecah batu.
Batu yang telah dipecahkan ada dua kategori yaitu pecahan kasar dan pecahan halus. Batu yang dipecahkan oleh perempuan pemecah batu di Desa Kebondalem masuk dalamkategoripecahan batukasaryanghanya menggunakan alat palu dan ban, sedangkan pecahan batu halus menggunakan alat yang dinamakan laser, dengan menggunakan alat laser ini hasil pecahan batunya lebih halus dan tidak kasar serta harganya lebih mahal. Jika pecahan batu kasar satu kibiknya dihargai Rp. 30.000,00 maka pecahan batu halus satu kibiknya dihargai Rp. 105.000,00 harga ini lebih mahal tiga kali lipatnya dari harga pecahan batu kasar.

Perbedaan yang tampak disini, bahwa jika pecahan batu kasar menggunakan alat yang masih tradisional yaitu palu dan ban sedangkan pecahan batu halus menggunakan alat yang sudah modern yaitu laser. Pecahan batu kasar memerlukan banyak tenaga dalam memecahkan dan dalam sehari yang dihasilkan lebih sedikit jika dibandingkan dengan batu yang dihasilkan dari laser, selain itu laser hanya menggunakan listrik sebagai tenaga untuk menggerakkannya.

Dalam memenuhi kebutuhan keluarga perempuan pemecah batu menyumbangkan $40 \%$ dari penghasilannya dan sisanya yang 60 $\%$ berasal dari penghasilan suami. Sedangkan $60 \%$ penghasilan istri dan $40 \%$ penghasilan suami digunakan untuk menabung, nyumbang dan digunakan untuk keperluan mendadak jika salah satu anggota keluarga ada yang sakit. Disini istri menyumbangkan

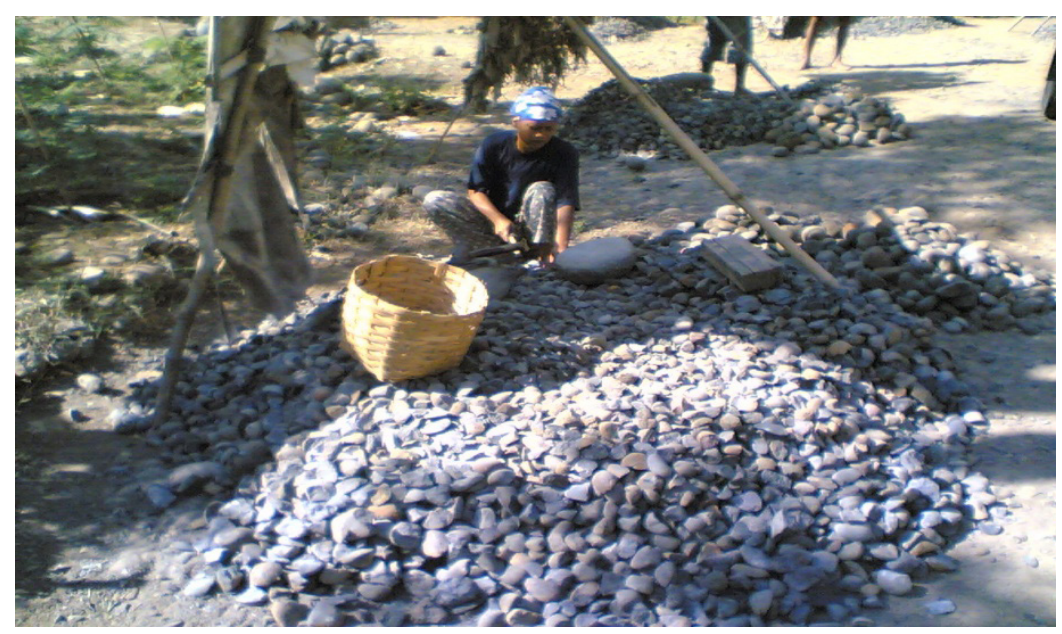

Gambar 2. Seorang perempuan pemecah batu yang sedang bekerja. 
pendapatannya lebih sedikit dibandingkan pendapatan yang disumbangkan oleh suami. Hal ini sesuai dengan yang diungkapkan oleh Ihromi (1999: 254) sumbangan tunai perempuan terhadap total pendapatan rumah tangga lebih kecil dibandingkan sumbangan pria, tetapi jumlah yang kecil itu " harus ada" agar rumah tangga dapat bertahan. Tanpa sumbangan perempuan ekonomi rumah tangga akan goyah. Walaupun ibu sudah ikut dalam menyumbangkan penghasilannnya untuk kebutuhan keluarga akan tetapi penghasilannya masih dianggap sebagai tambahan penghasilan keluarga.

Dorongan yang mengharapkan perempuan untuk membantu suami dalam menopang kehidupan ekonomi rumahtangga tampak sangat besar di daerah pedesaan. Sumbangan perempuan yang sangat tinggi dalam ekonomi rumahtangga ditunjukkan dengan munculnya konsep budaya tentang sumbangan suami maupun isteri. Sehingga dalam masyarakat jawa muncul istilah duwit lanang dan duwit wedok yang mengklasifikasikan penghasilan dan penggunaan pendapatan untuk menyebut pengeluaran tertentu. Duwit lanang yang berarti uang laki-laki (suami) biasanya berjumlah besar dan digunakan untuk kegiatan yang cenderung besar seperti mantu, biaya sekolah, membangun rumah dan sebagainya. Sementara duwit wedok berarti uang perempuan adalah pendapatan yang diperoleh perempuan ketika bekerja dibeberapa sektor di pedesaan seperti hasil pertanian kacang-kacangan dan lainlain. Dengan kata lain duwit wedok dapat digunakan untuk mencukupi kebutuhan sehari-hari keluarga seperti untuk makan, nyumbang, dan arisan (Abdullah 2003: 2002001)

Munculnya konsep jawa mengenai duwit lanang dan duwit wedok tersebut mengakibatkan duwit wedok hanya digunakan untuk kebutuhan tambahan sedangkan duwit lanang digunakan untuk kebutuhan yang lebih besar. Sehingga muncul anggapan bahwa pendapatan perempuan hanya sebagai tambahan pendapatan suami atau pendapatan sampingan, walaupun istri bekerja tidak dianggap sebagai penghasilan tetap.

Djamal (Sadli 1996: 235) anggapan bahwa perempuan bukan sebagai pencari nafkah utama menyebabkan pekerjaan perempuan menjadi tidak kelihatan dan tidak dianggap. Masyarakat dan perempuan sendiri merasa bahwa pekerjaannya hanya sebagai sambilan dan penghasilan perempuan adalah tambahan pendapatan keluarga.

Meskipun keadaan perempuan didunia kerja masih memprihatinkan terdapat dampak positif dari pembagian waktu perempuan dalam bekerja di area publik. Setelah perempuan di Desa Kebondalem bekerja sebagai pemecah batu, sedikit demi sedikit mulai memiliki peran dalam pengambilan keputusan. Hal ini karena perempuan di Desa Kebondalem telah ikut bekerja mencari nafkah, bahkan ada juga yang menjadi tulang punggung keluarga sehingga memiliki kekuasaan pengambilan keputusan dalam keluarga. Wewenang pengambilan keputusan dalam keluarga tidak hanya ditentukan sumber daya pribadi yang disumbangkan oleh suami dan istri dalam perkawinan tetapi juga dipengaruhi oleh struktur keluarga yang bersangkutan. Ihromi (1999: 87) menjelaskan bahwa pada umumnya pengambilan keputusan ada hubungannya dengan struktur kekuasaan dalam keluarga. Dengan kata lain, perubahan struktur keluarga akan dibarengi pula dengan perubahan dalam pembagian wewenang pengambilan keputusan dalam kehidupan keluarga.

Pola-pola pengambilan keputusan yang ditentukan suami adalah mengenai pendidikan anak dan menentukan jodoh bagi anak, akan tetapi istri tetap menyumbangkan saran meskipun keputusan besar tetap ada tangan suami. keputusan besar tersebut dibicarakan melalui musyawarah antara suami dan istri, karena apabila dari salah satu pihak saja akan mengakibatkan perbedaan pendapat. Jika terjadi perbedaan pendapat, istri tetap mengalah pada suami karena dalam masyarakat jawa ada anggapan bahwa istri seyogyanya harus patuh dan taat pada suami dan semua tindakannya harus seijin suami. 
Sedangkan pola-pola pengambilan keputusan yang ditentukan oleh istri seperti mengurus keuangan keluarga, memberikan uang saku kepada anak, membeli peralatan rumah tangga, menentukan pengeluaran sehari-hari keluarga dan sebagainya. Penjelasan tersebut dapat ditangkap dari wawancara dengan Bu Kodriyah berikut ini:

\section{Kulo seng ngatur artho keluargo amargi bojo kulo boten saged ngatur artho trus geh kulo wedi yen mengkeh diagem tumbas seng boten penting.}

(Saya yang mengatur keuangan keluarga karena suami tidak bisa mengatur keuangan keluarga selain itu juga saya takut kalau uangnya di gunakan untuk membeli yang tidak penting)

Perempuan atau istri lebih dipercaya oleh suami untuk mengatur keuangan keluarga. Geertz (Sayogjo 1999: 33) bahwa perempuan dalam keluarga jawa memiliki peranan yang lebih besar dalam proses pengambilan keputusan. Sebagai istri, perempuanlah yang mengelola keuangan keluarga. Hal ini sesuai dengan sifat perempuan yang lebih cermat dan teliti dalam mengatur keuangan keluarga dibandingkan laki-laki. disamping itu perempuan lebih tahu seberapa besar dan seberapa banyak kebutuhan keluarga, karena perempuanlah yang mengatur urusan rumah tangga sedangkan laki-laki sifatnya hanya membantu.

Pada wawancara pada tanggal 29 juli 2009, Bapak Khamid suami dari perempuan pemecah batu mengungkapkan pendapat yang hampir sama sebagai berikut:

Artho tak serahno kalian estri soale kulo boten saged ngatur artho mbak, trus seumpami kulo seng mbeto mengkeh arthone tak ge tumbas seng boten pentingpenting.

(Uang saya serahkan kepada istri karena saya tidak bisa mengatur keuangan mbak, kalau saya yang pegang nanti uangnya saya gunakan untuk membeli yang tidak penting)

Sebagai seorang ibu rumah tangga, aktivitas yang dijalankan perempuan pemecah batu di Desa Kebondalem tidak berbeda dengan aktivitas yang dijalankan perempuan terutama ibu-ibu pada umumnya. Sebelum berangkat kerja, perempuan pemecah batu memulai aktifitas pukul 5 pagi yaitu memasak, menyapu, mencuci dan membangunkan anak. Memasak dilakukan pertama kali sehabis bangun tidur setelah itu pergi ke sungai untuk mencuci pakaian sambil memandikan anak. Waktu yang digunakan perempuan pemecah batu untuk mengurus rumah tangga ada 10-11 jam dalam sehari.

Memasak makanan dilakukan satu kali dalam sehari yaitu sehabis mencuci pada pagi hari karena siang hari digunakan untuk

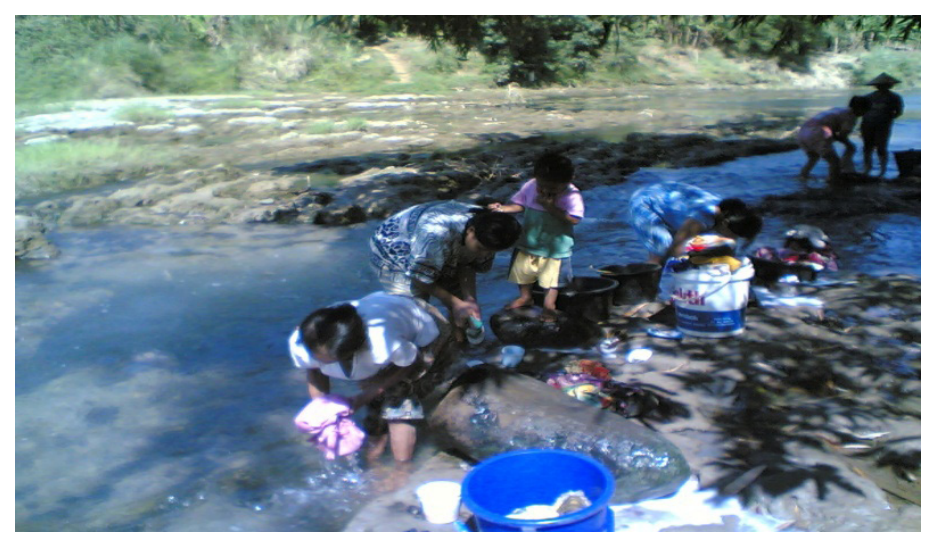

Gambar 3. Ibu-ibu pemecah batu yang sedang menjalankan peran ibu rumah tangga dengan mencuci pakaian keluarga. 
istirahat, sholat dan makan serta menyiapkan makan siang keluarga. Sedangkan sore harinya digunakan untuk mengurus suami, anak, menyapu halaman serta membersihkan rumah. Bagi yang memiliki anak perempuan aktifitas tersebut biasanya dibantu oleh anak. Sedangkan bagi perempuan pemecah batu yang anaknya masih kecil, aktifitas tersebut dikerjakan sendiri.

Dari beberapa wawancara dengan para perempuan pemecah batu, dapat dilihat bahwa begitu berat beban kerja yang dijalani perempuan sebagai seorang istri dan sebagai ibu rumah tangga. Seorang istri dan sebagai ibu rumah tangga harus bisa memasak, mencuci, menyapu dan mengasuh anak yang dilakukan setiap hari tanpa menggangu aktifitas bekerja sebagai pemecah batu. Hal ini dikarenakan kesadaran mereka bahwa perempuan tugasnya adalah sebagai ibu rumah tangga, kalaupun bekerja tidak boleh meninggalkan pekerjaannya sebagai ibu rumah tangga. Keluarga tetap diprioritaskan agar hubungan dengan anak dan suami tetap terjalin dengan baik. Disamping itu perempuan pemecah batu harus bisa membagi waktu antara urusan domestik atau rumah tangga dan publik atau mencari nafkah.

Secara ekonomi, perempuan pemecah batu di Desa Kebondalem bisa dikatakan miskin. Dalam satu bulan pendapatan perempuan pemecah batu hanya sebesar Rp. 180.000,00. uang sebesar itu tidak cukup untuk memenuhi kebutuhan sehari-hari. Apalagi jika dalam satu keluarga hanya suami yang bekerja maka uang sebesar itu tidak mencukupi kebutuhan sehingga untuk meningkatkan kesejahteraan keluarga, perempuan di Desa Kebondalem memilih pekerjaan sebagai pemecah batu.

Menurut Suparlan (1984: 12), kemiskinan adalah suatu standar tingkat hidup yang rendah yaitu adanya suatu tingkat kekurangan materi pada sejumlah atau segolongan orang dibandingkan dengan standar kehidupan yang umum berlaku dalam masyarakat yang bersangkutan.

Jika dikaitkan dengan kemiskinan multidimensi, perempuan Desa Kebondalem mengalami kemiskinan pendapatan, pendidikan dan ketimpangan gender. Kemiskinan pendapatan karena pendapatan yang diperoleh belum mampu untuk memenuhi kebutuhan keluarga dan belum bisa meningkatkan kesejahteraan keluarga. Pendapatan tersebut hanya cukup untuk memenuhi kebutuhan sehari-hari dan tidak ada sisa untuk membeli kebutuhan tambahan. Kemiskinan pendidikan mengacu pada tingkat pendidikan, sebagian besar hanya menempuh pendidikan setingkat $\mathrm{SD}$, sehingga perempuan kurang memiliki keahlian khusus dan sumber daya manusianya rendah. Sedangkan ketimpangan gender, perempuan di Desa Kebondalem memiliki peran ganda yaitu sebagai ibu rumah tangga dan sebagai pencari nafkah keluarga.

Buruh perempuan pemecah batu masuk dalam kategori kemiskinan struktural karena sebagian besar perempuan yang bekerja sebagai pemecah batu di Desa Kebondalem tidak memiliki lahan, tingkat pendidikan yang hanya SD dan tidak memiliki keterampilan.

\section{SIMPULAN}

Berdasarkan hasil penelitian dan analisis yang dilakukan dapat disimpulkan bahwa para perempuan pemecah batu mendapatkeuntungandenganbekerjasebagai pemecah batu karena dapat memperluas hubungan sosial dengan masyarakat luas dan tidak hanya berinteraksi dengan anak dan suami. Kehidupan ekonomi para perempuan pemecah batu tidak mengalami perubahan karena pendapatan yang diperoleh belum mampu untuk memenuhi kebutuhan primer, sekunder dan tersier.

Pola pengambilan keputusan dalam keluarga perempuan pemecah batu ada hal-hal tertentu yang didominasi oleh istri atau perempuan terutama dalam hal yang berkaitan dengan urusan domestik. Dalam masyarakat "petani" pekerjaan domestik diserahkan kepada perempuan karena golongan ini dianggap cocok dan dapat diandalkan demi kepentingan seluruh anggota keluarganya. Namun demikian dalam hal-hal yang berkaitan dengan aktivitas pengasuhan, pendidikan, dan kesehatan 
relatif dilakukan secara bersama antara suami dan istri. Adapun dalam alokasi waktu yang digunakan perempuan pemecah batu untuk bekerja dan mengurus rumah tangga lebih banyak jika dibandingkan oleh suami mereka, sehingga perempuan pemecah batu memiliki beban yang lebih berat jika dibandingkan dengan suami mereka karena selain sama - sama mencari nafkah, masih harus mengurus sendirian pekerjaan rumah tangga.

\section{DAFTAR PUSTAKA}

Abdullah, I. 2003. Sangkan Paran Gender. Yogyakarta: Pustaka Pelajar.

Daulay, H. 2006. Pemberdayaan Perempuan (Studi Kasus Pedagang Jamu di Gedung Johor Medan). Universitas Sumatera Utara. Jurnal
Harmoni Sosial Vol. I No.1. September 2006.

Fakih, M. 2006. Analisis Gender dan Transformasi Sosial. Yogyakarta: Pustaka Pelajar

Ihromi, TO. 2004. Bunga Rampai Sosiologi Keluarga. Jakarta: Yayasan Obor Indonesia.

Sadli, S. 1997. Perempuan Kerja dan Perubahan Sosial. Jakarta: PT. Pusaka Utama Grafiti.

Sajogyo, P. 1983. Peranan Wanita Dalam Perkembangan Masyarakat Desa. Jakarta: CV. Rajawali.

Silvia, S. 2009. Beberapa Faktor Yang Mempengaruhi Tingkat Partisipasi Angkatan Kerja Wanita Di Provinsi Aceh. Universitas Syiah Kuala. Jurnal Ekonomi dan Bisnis. 8 (1), April, 2009:77-91.

Suparlan, P. 1984. Kemiskinan Di Perkotaan. Jakarta: Sinar Harapan

Supartiningsih. 2003. Peran Ganda Perempuan, Sebuah Analisis Filosofis Kritis. Universitas Gadjah Mada. Jurnal Filsafat. 33(1): 42-54.

Christina, W.T.2010. Etos Kerja dan Kehidupan Sosial Ekonomi Profesi. Jurnal Komunitas. 2(1) : 3153. 